\title{
Incidence and outcome of gestational trophoblastic disease in lower Egypt
}

\author{
Ahmed Zakaria, Reda Hemida, Waleed Elrefaie, Ehsan Refaie
}

Mansoura University Faculty of Medicine.

\begin{abstract}
Background. Gestational trophoblastic disease (GTD) defines a spectrum of proliferative disorders of trophoblastic epithelium of the placenta. Incidence, risk factors, and outcome may differ from one country to another.

Objective. To describe incidence, patient characteristics, treatment modalities, and outcome of GTD at Mansoura University which is a referral center of Lower Egypt.

Methods. An observational prospective study was conducted at the GTD Clinic of Mansoura University. The patients were recruited for 12 months from September 2015 to August 2016. The patients' characteristics, management, and outcome were reported.

Results. We reported 71 clinically diagnosed GTD cases, 62 of them were histologically confirmed, 58 molar (33 CM and 25 PM) in addition to 4 initially presented GTN cases. Mean age of the studied cases was 26.22 years \pm 9.30 SD. Mean pre-evacuation hCG was 136170 m.i.u/ml \pm 175880 SD. Most of the cases diagnosed accidentally after abnormal sonographic findings $(53.2 \%)$. Rate of progression of CM and PM to GTN was $24.2 \%$ and $8 \%$, respectively.

Conclusion. The incidence of molar pregnancy and GTN in our locality was estimated to be 13.1 and 3.2 per 1000 live births respectively. We found no significance between CM and PM regarding hCG level, time to hCG normalization, and progression rate to GTN.

Keywords. Molar pregnancy; incidence; outcome.

DOI: https://dx.doi.org/10.4314/ahs.v20i1.12

Cite as: Zakaria A, Hemida R, Elrefaie W, Refaie E. Incidence and outcome of gestational trophoblastic disease in lower Egypt. Afri Health Sci. 2020;20(1):73-82. bttps://dx.doi.org/10.4314/abs.v20i1.12
\end{abstract}

\section{Introduction}

Gestational trophoblastic disease (GTD) defines a spectrum of proliferative disorders of trophoblastic epithelium of the placenta ${ }^{1}$. GTD was classified histologically into benign forms of complete and partial hydatidiform moles and malignant forms of invasive moles, gestational choriocarcinoma, placental site trophpoblastic tumors (PSTT), and epithelioid trophoblastic tumors². The incidence of gestational trophoblastic disease differs according to geographic distribution. The highest reported incidence was 1/125 live births in Taiwan, while 2/1000 pregnancies in Japan and South East Asia, 1/1500 in United States and 1/1000 in Europe ${ }^{3}$. However, underestimation of the molar pregnancy incidence may occur if the products oconception are not routinely subjected

\section{Corresponding author: \\ Reda Hemida, \\ Mansoura University \\ Faculty of Medicine. \\ Email: redaelshouky@hotmail.com}

to histological examination and if the registry system is not developed ${ }^{4}$. Risk factors of molar pregnancy include genetic, racial ${ }^{5}$, extremes of maternal age $\mathrm{e}^{6,7}$, dietary and nutritional factors ${ }^{8}$.

Hydatidiform moles typically are diagnosed during the first trimester'. Abnormal vaginal bleeding is the commonest symptom. Other signs and symptoms include hyperemesis gravidarum, oversized uterus, absent fetal heart pulsations, pregnancy induced hypertension and abnormally high levels of $\mathrm{hCG}^{10}$. By ultrasound, molar tissue is usually identified as a diffuse mixed echogenic pattern replacing the placenta (snowstorm), produced by villi with intervening intrauterine blood clots ${ }^{11}$. Treatment of molar pregnancy is by suction evacuation with a soft plastic cannula ${ }^{12}$ with ultrasound control. Following evacuation, it is mandatory to monitor all patients to diagnose and treat malignant progression.

Post-molar GTN is typically diagnosed in patients with serum B-hCG raised, plateau, or persistent beyond 6 months of molar evacuation ${ }^{13}$. GTN are categorized into

(C) 2020 Zakaria A et al. Licensee African Health Sciences. This is an Open Access article distributed under the terms of the Creative commons Attribution License (https://creativecommons.org/licenses/BY/4.0), which permits unrestricted use, distribution, and reproduction in any medium, provided the original work is properly cited. 
low or high risk according to the International Federation of Gynaecology and Obstetrics (FIGO) staging and modified World Health Organization (WHO) risk-factor scoring system ${ }^{14}$. Patients with FIGO stages I-III with a score of $0-6$ are categorized as low-risk GTN while either FIGO stage IV or any stage with WHO score $\geq 7$ are classified as high risk ${ }^{15}$. GTN is well known to be highly responsive to chemotherapy. Low-risk GTN is cured with single-agent chemotherapy with either methotrexate or actinomycin-D in $90 \%$ of the cases ${ }^{16}$. High-risk GTN is treated with combination chemotherapy to optimize outcome ${ }^{17,18}$.

Since the incidence, patients, characteristics, treatment modalities, and outcome of gestational trophoblastic disease may differ from country to another; we conducted this prospective study to describe our early experience in Gestational Trophoblastic Clinic, Mansoura University, Egypt.

\section{Methods}

An observational prospective study was conducted at the GTD Clinic of Mansoura University Hospitals, Mansoura, Egypt. Mansoura University Hospital provides tertiary healthcare for most of the Delta region of Egypt, with a population of about 12 millions. The patients were recruited for 12 months (from September 2015 to August 2016), followed by 6 months so that the follow up was at least 6 months for all patients.

\section{Participants. \\ Inclusion criteria}

The current study included both molar pregnancies and GTN. Molar pregnancies were diagnosed clinically and based on ultrasound criteria with an abnormally high hCG levels. Patients presented by gestational trophoblastic neoplasia included postmolar GTN (with serum $\beta$-hCG raised, plateau, or persistent beyond 6 months of molar evacuation) or cases with histological evidence of choriocarcinoma, invasive mole, PSTT, and epithelioid trophoblastic tumors.

\section{Exclusion criteria}

Histologic confirmation of "products of conception" after suction evacuation and patients who refused to participate in the study.

Collected patient variables included the age, the body mass index, parity, gestational age, uterine size in weeks, sonographic findings, serum $\beta$-hCG, lung metastasis, and medical diseases were recorded. To get a rough estimate of prevalence of GTD in our Hospital; the included cases were compared to the whole number of live births in Mansoura University Hospitals.

\section{Treatment of molar pregnancy}

1. Pre-operative preparation: routine laboratory tests, $\beta$-hCG, chest X-ray and anaesthetic consultation were performed.

2. The patients were treated by suction evacuation using a soft plastic cannula, guided by ultrasonography under short acting general anaesthesia. After dilation of the cervix; Oxytocin 5 IU ampoule (Syntocinon, Novartis, Egypt) was given in $500 \mathrm{ml}$ saline infusion in case of severe uterine bleeding during suction evacuation. After the procedure was completed; Ergometrine $0.2 \mathrm{mg}$ ampoule (Methergine, Novartis, Egypt) was given intramuscular to reduce uterine bleeding. Prophylactic broad spectrum antibiotic was given. The patient was discharged 48 hours after evacuation.

3. Follow up. The patients were followed by serum $\beta$-hCG weakly till 3 negative results (below the reference range of 5 m.I.U/mL). Subsequently, hCG was checked monthly for 6 months to insure that the hCG levels remained undetectable. During the post evacuation management, the patients were under the umbrella of contraception; preferably combined oral contraception pills.

\section{Diagnosis, staging, and risk factors for gestational trophoblastic neoplasia}

Progression to GTN was diagnosed using the FIGO, 2002 criterion $^{15}$ : hCG levels rising (more than 10\%) for three consecutive weeks, plateaued for four weeks or persistent beyond 6 months. Patients with a histological diagnosis of any of the malignant forms or metastases detected during post-molar follow-up were also classified as GTN cases. GTN was staged according to the FIGO, 2002 criteria and classified into low or high risk according to modified WHO scoring system. The diagnosed cases as GTN were discussed in the tumor board meetings to receive chemotherapy and possibility of surgical interference.

\section{Ethical considerations}

Oral and written consent was taken from the patients. The study was approved by the institutional review board 
(IRB) of Faculty of Medicine, Mansoura University (number: MS/16.01.01).

\section{Statistical analysis}

Data were analyzed with SPSS version 21. The normality of data was first tested with one-sample Kolmogorov-Smirnov test. Qualitative data were described using number and percent. Association between categorical variables was tested using Chi-square and Fischer exact tests. Continuous variables were presented as mean \pm SD (standard deviation) for parametric data and median (Min-Max) for non-parametric data. The two groups were compared with Student t test for parametric data and Mann Whitney test for non-parametric data. $P$ values were considered statistically significant when $\mathrm{p}<0.05$.

\section{Results}

Between $1^{\text {st }}$ of September 2015 till the $31^{\text {st }}$ of August 2016, 71 clinically diagnosed patients as GTD were included in the study. Sixty-two were confirmed histologically to have GTD (58 cases of molar pregnancy and 4 cases of GTN). The total number of life births in $\mathrm{MUH}$ during the same period was 4398 thus the incidence of molar pregnancy and GTN in MUH is estimated to be 13.1 and 3.2 per 1000 live births respectively. In the same period of time, the number of live births in Dakahlia governorate was 155,962 representing a population-based incidence of molar pregnancy and GTN 0.37 and 0.09 per 1000 live birth respectively. The mean age of the cases with molar pregnancy was $26.22 \pm 9.30$ years with $16.1 \%$ of the cases are less than 18 years old and $12.9 \%$ are 40 years old or more. We reported one case with familial recurrent hydatidiform moles where CM was diagnosed in her 2 sisters. Genetic study was done for the sisters and revealed a mutation of NLRP7.Other socio-demographic criteria were shown in table 1 . The clinical presentation of the studied cases is demonstrated in table 2 , as can be noticed; thirty-three cases (53.2\%) were accidentally diagnosed by ultrasound during routine antenatal care visits. Chest X-ray was free for all diagnosed cases. The sensitivity of ultrasound in diagnosis of molar pregnancy was calculated to be $87 \%$ while the sensitivity, specificity, positive predictive value, negative predictive value, and accuracy of ultrasound in differentiating complete and partial moles is presented in table 3 which were found to be $96.7 \%, 73.6 \%, 85.2 \%, 93.3 \%$, and $87.7 \%$ respectively. 
Table 1: Demographic data of newly diagnosed cases of GTD in one year

\begin{tabular}{|c|c|c|}
\hline \multirow{2}{*}{ Variables } & \multicolumn{2}{|c|}{$\begin{array}{l}\text { The study group } \\
(\mathrm{n}=62)\end{array}$} \\
\hline & No & $\%$ \\
\hline $\begin{array}{l}\text { Age (years) } \\
<18 \\
18 \text { to }<40 \\
\geq 40\end{array}$ & $\begin{array}{l}10 \\
44 \\
8\end{array}$ & $\begin{array}{l}16.1 \% \\
71.0 \% \\
12.9 \%\end{array}$ \\
\hline $\begin{array}{l}\text { Mean } \pm \text { SD } \\
\text { (Min.-Max.) }\end{array}$ & \multicolumn{2}{|l|}{$\begin{array}{l}26.22 \pm 9.30 \\
16-52\end{array}$} \\
\hline $\begin{array}{l}\text { BMI* } \\
\text { Mean } \pm \text { SD } \\
\text { (Min.-Max.) }\end{array}$ & \multicolumn{2}{|l|}{$\begin{array}{l}24.55 \pm 4.01 \\
19-35\end{array}$} \\
\hline $\begin{array}{l}\text { Parity } \\
\text { Nullipara \& Primi para } \\
\text { Multipara }\end{array}$ & $\begin{array}{l}33 \\
29 \\
\end{array}$ & $\begin{array}{l}53.2 \% \\
46.8 \% \\
\end{array}$ \\
\hline $\begin{array}{l}\text { Mode of delivery }(n=42) \\
\text { Cesarean section } \\
\text { Vaginal delivery }\end{array}$ & $\begin{array}{l}24 \\
18\end{array}$ & $\begin{array}{l}57.1 \% \\
42.9 \%\end{array}$ \\
\hline History of miscarriage & 22 & $35.5 \%$ \\
\hline $\begin{array}{l}\text { Medical diseases } \\
\text { Anemia } \\
\text { Asthma } \\
\text { Diabetes } \\
\text { Hypertension } \\
\text { Hyperthyrodism } \\
\text { Hypothyrodism } \\
\text { Deep venous thrombosis }\end{array}$ & $\begin{array}{l}\mathbf{n}=\mathbf{2 3} \\
15 \\
2 \\
2 \\
1 \\
1 \\
1 \\
1\end{array}$ & $\begin{array}{l}37.1 \% \\
65.2 \\
8.7 \\
8.7 \\
4.3 \\
4.3 \\
4.3 \\
4.3\end{array}$ \\
\hline Positive family history & 1 & $1.6 \%$ \\
\hline
\end{tabular}

${ }^{*}$ BMI: Body Mass Index.

Positive family history**: Recurrent $\mathrm{CHM}$ was diagnosed in her 2 sisters. 
Table 2: Clinical presentation of the studied cases

\begin{tabular}{|l|l|l|}
\hline $\begin{array}{l}\text { Clinical presentation } \\
(\mathrm{n}=\mathbf{6 2})\end{array}$ & No & $\%$ \\
\hline Diagnosed by ultrasound & 33 & 53.2 \\
\hline Vaginal bleeding & 21 & 33.9 \\
\hline Hyperemesis gravidarum & 4 & 6.5 \\
\hline $\begin{array}{l}\text { Lower abdominal pain with } \\
\text { pregnancy }\end{array}$ & 2 & 3.2 \\
\hline $\begin{array}{l}\text { Stoppage of menstrual } \\
\text { cycle above 50 years old }\end{array}$ & 1 & 1.6 \\
\hline Early onset Preeclampsia* & 1 & 1.6 \\
\hline
\end{tabular}

$\left(^{*}\right)$ One patient was admitted in the Neurology department because of convulsive fits and was diagnosed to have early onset preeclampsia with molar pregnancy.

Table 3: Accuracy of ultrasound in differentiating complete and partial moles.

\begin{tabular}{|c|c|c|c|c|}
\hline \multirow{5}{*}{$\begin{array}{l}\text { U/S } \\
\text { Diagnosis }\end{array}$} & & \multicolumn{2}{|l|}{ Histopathology } & \multirow{2}{*}{ Total } \\
\hline & & Complete mole & Partial mole & \\
\hline & $\begin{array}{l}\text { Complete } \\
\text { mole }\end{array}$ & 29 & 5 & 34 \\
\hline & Partial mole & 1 & 14 & 15 \\
\hline & Total & 30 & 19 & 49 \\
\hline
\end{tabular}

In table 4, complete and partial mole were compared regarding the demographic and clinical data; the age and existence of bilateral theca lutein cysts were significantly different between two types of moles $(\mathrm{P}=0.045 \& 0.024$ respectively), there were no significant differences regarding pre-evacuation hCG $(\mathrm{P}=0.29)$, and mean time to hCG normalization $(\mathrm{P}=0.16)$. The rate of $\mathrm{hCG}$ decline after complete and partial molar evacuation was shown in figure 1.The percentage of cases which transformed to GTN is $24.2 \%$ in complete mole and $8 \%$ in partial mole $(\mathrm{P}=0.105)$.

Fourteen GTN cases were reported; ten cases resulted progression of molar cases during follow up and four cases initially presented as GTN. All cases were low-risk (FIGO score 1-5). One case of invasive mole aged 42 years was treated with upfront hysterectomy with one course of methotrexate. Thirteen cases received 8 days regimen of intramuscular methotrexate-folinic acid; two of them failed to respond and were shifted to EMA/CO (etoposide, methotrexate, actinomycine D, cyclophosphamide and vincristine combination). One of these two cases who failed to combination chemotherapy underwent local myometrial resection followed by 2 courses of EMA/EP (etoposide, methotrexate, actinomycin D, etoposide, cisplatin) followed by hCG normalization.

African Health Sciences Vol 20 Issue 1, March, 2020 
Table 4: Comparison between complete and partial mole regarding demographic and clinical data

\begin{tabular}{|c|c|c|c|}
\hline Variables & $\begin{array}{l}\text { Complete mole } \\
(n=33) 57 \%\end{array}$ & $\begin{array}{ll}\text { Partial } & \\
\text { mole } & (n=25) \\
43 \% & \\
\end{array}$ & $p$-value \\
\hline Age/years & $27.66 \pm 10.71$ & $23.20 \pm 5.53$ & 0.045 \\
\hline $\begin{array}{l}<18 \\
18-<40 \\
\geq 40\end{array}$ & $\begin{array}{l}7(21.2 \%) \\
21(63.6 \%) \\
5(15.2 \%) \\
\end{array}$ & $\begin{array}{l}3(12.0 \%) \\
21(84.0 \%) \\
1(4.0 \%) \\
\end{array}$ & 0.199 \\
\hline BMI & $25.00 \pm 4.07$ & $23.88 \pm 3.51$ & 0.276 \\
\hline $\begin{array}{l}\text { Parity } \\
\text { Null\& Primi para } \\
\text { Multipara }\end{array}$ & $\begin{array}{l}19(57.6 \%) \\
14(42.4 \%) \\
\end{array}$ & $\begin{array}{l}13(52.0 \%) \\
12(48.0 \%) \\
\end{array}$ & 0.672 \\
\hline Gest. Age (weeks) & $8.75 \pm 2.30$ & $9.72 \pm 3.12$ & 0.183 \\
\hline $\begin{array}{l}\text { Mode of delivery } \\
\text { Caesarean Section } \\
\text { Vaginal Delivery }\end{array}$ & $\begin{array}{l}12(54.5 \%) \\
10(45.5 \%)\end{array}$ & $\begin{array}{l}12(66.7 \%) \\
6(33.3 \%)\end{array}$ & 0.436 \\
\hline \begin{tabular}{|l|} 
History of abortion \\
Med. Disease \\
\end{tabular} & $\begin{array}{l}11(33.3 \%) \\
7(29.2 \%) \\
\end{array}$ & \begin{tabular}{|l|}
$9(36.0 \%)$ \\
$8(33.3 \%)$ \\
\end{tabular} & 0.832 \\
\hline $\begin{array}{l}\text { Complaint } \\
\text { Vaginal Bleeding } \\
\text { Hyperemesis } \\
\text { diagnosed by U/S } \\
\text { PET } \\
\text { Pelvic Pain }\end{array}$ & $\begin{array}{l}9(27.3 \%) \\
3(9.1 \%) \\
21(63.6 \%) \\
0(0.0 \%) \\
0(0.0 \%)\end{array}$ & $\begin{array}{l}11(44.0 \%) \\
1(4.0 \%) \\
11(44.0 \%) \\
1(4.0 \%) \\
1(4.0 \%)\end{array}$ & 0.324 \\
\hline \multicolumn{4}{|l|}{ Theca Leutin Cysts } \\
\hline $\begin{array}{l}\text { free } \\
\text { Bilateral and }>6 \mathrm{~cm} \\
\end{array}$ & $\begin{array}{l}27(81.8 \%) \\
6(18.2 \%) \\
\end{array}$ & \begin{tabular}{|l|}
$25(100 \%)$ \\
$0(0 \%)$ \\
\end{tabular} & 0.024 \\
\hline $\begin{array}{l}\text { Blood transfusion } \\
\text { need during } \\
\text { evacuation }\end{array}$ & $23(69.7 \%)$ & $12(48.0 \%)$ & 0.094 \\
\hline $\begin{array}{l}\text { Mean pre-evacuation } \\
\text { hCG (m.i.u/ml) } \\
\text { Median (Min-Max) } \\
\text { Mean } \pm \text { SD }\end{array}$ & $\begin{array}{l}88810(3210- \\
831000) \\
162970 \pm 190737\end{array}$ & $\begin{array}{l}65109(4300- \\
780000) \\
107230 \pm 161652\end{array}$ & 0.29 \\
\hline $\begin{array}{l}\text { Mean time to hCG } \\
\text { normalization(weeks) } \\
\text { Median (Min-Max) }\end{array}$ & $\begin{array}{l}8.5(5-60) \\
11.37 \pm 10.8\end{array}$ & $\begin{array}{l}10(5-16) \\
10.26 \pm 2.37\end{array}$ & 0.16 \\
\hline Progression to GTN & $8 / 33(24.2 \%)$ & $2 / 25(8 \%)$ & 0.105 \\
\hline
\end{tabular}




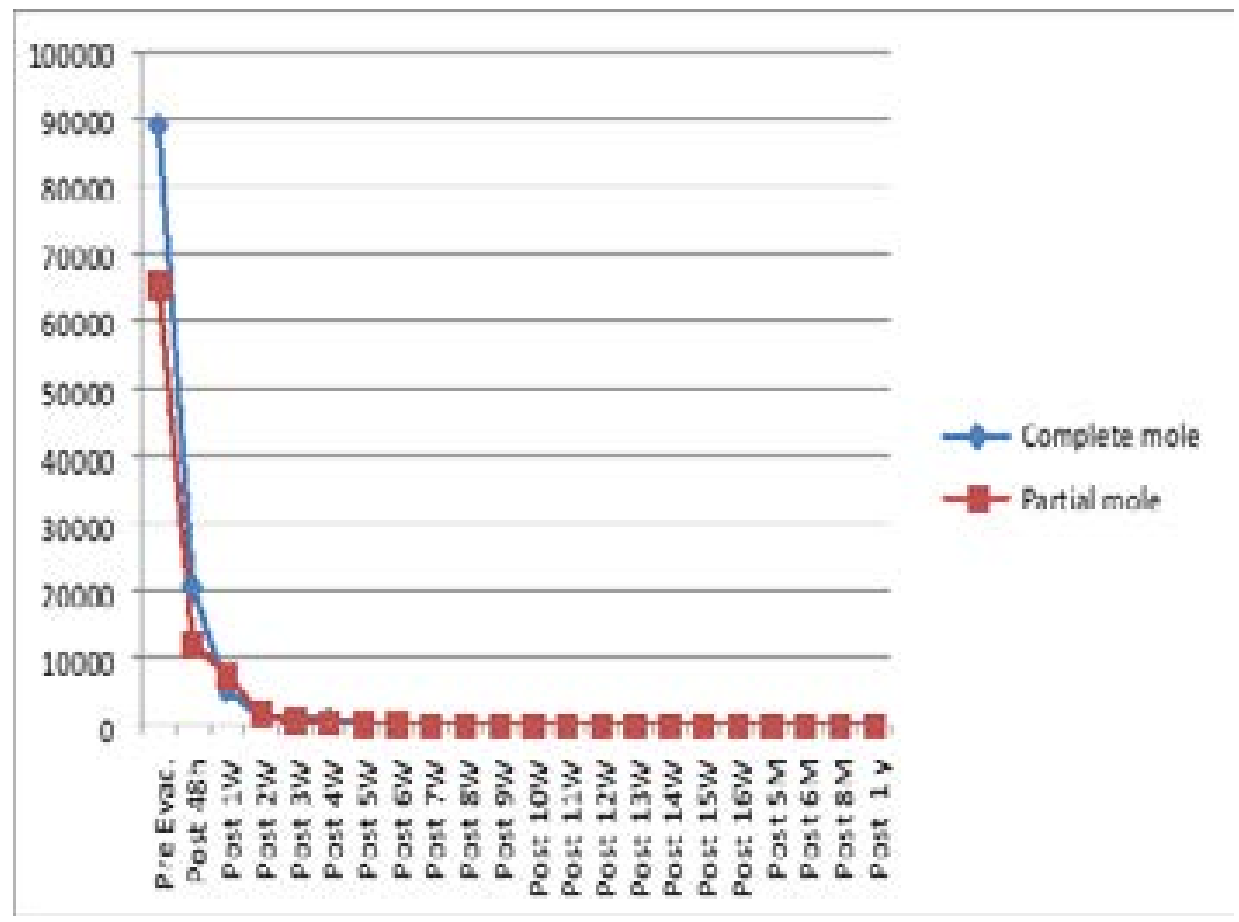

Figure 1: Comparison between complete and partial mole regarding different hCG levels before and after evacuation.

\section{Discussion}

We reported for first time hospital -based and population - based incidence of molar pregnancy in Lower-Egypt population of 13.1 and 0.37 per 1000 live births respectively. Since data on the total number of pregnancies are not available; the denominator is live births which underestimate the population at risk which may result in a small overestimation of the incidence rates observed in the current study. The hospital-based incidence is more than reported in Taiwan (8.0 per 1000 deliveries), Indonesia (9.9 per 1000 pregnancies). Furthermore, our population based incidence is less than reported in the Netherlands (0.68 per 1000), Japan (3.0 per 1000) and England (1.54 per 1000) ${ }^{19}$. However, in Egypt and many developing countries spontaneous abortions specimens are not routinely subjected to histopathologic review and registration.

In this study, the mean age was $26.22 \pm 9.30$ years with $71.0 \%$ of the cases between 18 and 40 years old which is quiet understandable as this is the child bearing age period for women with the maximum number of pregnancies which reported also by other authors ${ }^{20-22}$. The mode of delivery of the studied cases was; $57.1 \%$ caesarean deliveries and $42.9 \%$ vaginal deliveries which is compatible with the increasing trend in caesarean section rates in
Egypt $^{23}$. The percentage of the cases with previous history of abortion was $35.5 \%$, a history of prior spontaneous abortion has been reported to give women a two to three-fold increase in molar pregnancy compared to a woman without such a history ${ }^{24}$. Anemia was the most common medical disease affecting $65.2 \%$ of the studied cases which goes with the previous studies concerning anemia among pregnant women in $\mathrm{Egypt}^{25}$.

In this study, we found that $53.2 \%$ of molar pregnancies were asymptomatic and accidentally discovered by ultrasonography which agreed with Joneborg et $\mathrm{al}^{26}$ who reported that patients with vesicular mole were diagnosed before the onset of symptoms in $42.5 \%$ of cases, while Sun SY et $\mathrm{al}^{27}$ reported that the most common presentation was vaginal bleeding in $46 \%$ compared with $33.9 \%$ in the current study. The sensitivity of ultrasound forccurately diagnosing hydatidiform mole was $87 \%$, though Fowler et al and Kirk et $\mathrm{al}^{28}$ reported that the sensitivity of ultrasound for accurately predicting hydatidiform mole was 44\%. This discrepancy may be attributed to small sample size of our study.

The median level of hCG decline after molar evacuation for any type of GTD was 9 weeks which is earlier than reported by Delattre et al which was 12.3 weeks $^{29}$ which 
may explained by different patient criteria. Furthermore, we found that the GTN sequel during follow up was 10 cases $(16.1 \%)$. Joneborg et $\mathrm{al}^{30}$ reported that the risk of post-molar GTN was $8 \%$ in his study, though Schmitt et $\mathrm{al}^{31}$ found that GTN developed in $12.1 \%$ of his cohort study. The variation of molar progression to GTN in different studies may reflect different outcome among different countries.

In literature a wide range of ratios of complete mole to partial mole incidence has been reported ranging from 0.3 to 3.032. In the present study; 33 complete mole case to 25 partial mole cases of total 58 cases with a ratio of 1.3. Morphologically, both complete mole and partial mole have distinct histopathological features; however, the subjective nature of the morphological characters may give rise to variation in diagnosis ${ }^{33}$. In particular when earlier evacuation is performed in the present ultrasound era, classic morphological features may be less distinct ${ }^{34}$. The differentiation between molar and non-molar gestations is usually clear in cases showing typical histological features, and in cases of complete mole this is confirmed by p57 immunohistochemistry ${ }^{35}$. However, the diagnosis of partial mole can still be confusing, even to specialized gynecological pathologists ${ }^{36}$ and this is important clinically in view of the risk of GTN progression in these patients. Moreover, hydropic abortion has traditionally been considered the major differential diagnosis of partial mole ${ }^{37}$. The trend toward earlier diagnosis for both complete mole and partial mole observed in our center is consistent with the global trends as the median gestational age at evacuation was $8.75 \pm 2.30$ weeks for complete mole and $9.72 \pm 3.12$ weeks for partial mole. Sun et al reported The median gestational age at evacuation was 9 weeks for complete mole and 12 weeks for partial mole ${ }^{38}$ and reported in another study ${ }^{29}$ that the median gestational age at diagnosis continued to decrease in two non-concurrent cohorts (1988-1993 versus 1994-2013) of patients from the New England Trophoblastic Disease Center; 9 weeks versus 12 weeks. Blood transfusion was required during evacuation of $69.7 \%$ of cases of complete moles and $48.0 \%$ of partial moles. This figure is much more than reported by authors at the New England Trophoblastic Disease Center ${ }^{39}$. The high rate of blood transfusion in our study may be attributed to higher incidence of anemia in Egyptian pregnant women which was reported by some authors ${ }^{25}$ and correlated to high prevalence of anemia among the studied cases that was $65.2 \%$.

The current study has limitations that Mansoura University Hospital is a regional referral center, and, therefore, our patient population may not be representative of the entire patient population. The reported data could be influenced by referral bias. Furthermore, immunohistochemical staining with P57 is not used routinely to differentiate between partial and early complete moles which may result in relatively higher incidence of partial moles. Centralization of GTD work allows proper estimation of incidence, sharing expertise at the national level, and help implementation of clear guidelines of diagnosis and treatment of GTD cases ${ }^{40}$.

\section{Conclusion}

The incidence of molar pregnancy and GTN at Mansoura University Hospitals is estimated to be 13.1 and 3.2 per 1000 live births respectively. Ratio of complete to partial moles was 1.3. Fifty-three percent of the cases were accidentally discovered by ultrasound. We found no significance between CM and PM regarding mean pre-evacuation hCG level, mean time to hCG normalization, and rate of progression to GTN which need to be verified in future studies.

\section{Conflict of interest}

The authors declare that there are no conflicts of interest. The authors received no funding or grants.

\section{Acknowledgement}

Authors appreciated the work of Helena C. van Doorn, $\mathrm{MD}, \mathrm{PhD}$, Eramus MC, Rotterdam, the Netherlands in supervision of the study and continues support of Mansoura GTD clinic.

\section{References}

1- Lurain JR. Gestational trophoblastic disease I: epidemiology, pathology, clinical presentation and diagnosis of gestational trophoblastic disease, and management of hydatidiform mole. Am J Obstet Gynecol. 2010 Dec;203(6):531-9.

2- Seckl M, Sebire N, Fisher R, Golfier F, Massuger L, Sessa C, et al. Gestational trophoblastic disease: ESMO Clinical Practice Guidelines for diagnosis, treatment and follow-up. Ann Oncol. 2013;24(suppl_6):vi39-vi50.

3- Tse KY, Chan KK, Tam KF, Ngan HY. An update on gestational trophoblastic disease. Obstetrics, Gynaecology and Reproductive Medicine. Geburtshilfe Frauenbeilked. 2012;22(1):7-15.

4- Seckl MJ, Sebire NJ, Berkowitz RS. Gestational trophoblastic disease. Lancet. 2010;376(9742):717-29.

5- Gockley AA, Joseph NT, Melamed A, Sun SY, 
Goodwin B, Bernstein M, et al. Effect of race/ethnicity on clinical presentation and risk of gestational trophoblastic neoplasia in patients with complete and partial molar pregnancy at a tertiary care referral center. $A m \mathrm{~J}$ Obstet Gynecol. 2016;215(3):334.e1-6.

6- $\quad$ Savage P, Sita-Lumsden A, Dickson S, Iyer R, Everard J, Coleman R, et al. The relationship of maternal age to molar pregnancy incidence, risks for chemotherapy and subsequent pregnancy outcome. J Obstet Gynaecol. 2013;33(4):406-11.

7- Gockley AA, Melamed A, Joseph NT, Clapp M, Sun SY, Goldstein DP, et al. The effect of adolescence and advanced maternal age on the incidence of complete and partial molar pregnancy. Gynecol Oncol. 2016;140(3):470-3. 8- Candelier J-J. The hydatidiform mole. Cell Adh Migr. 2016;10(1-2):226-35.

9- Cavaliere A, Ermito S, Dinatale A, Pedata R. Management of molar pregnancy. J Prenat Med. 2009;3(1):15-7. 10- Hou JL, Wan XR, Xiang Y, Qi QW, Yang XY. Changes of clinical features in hydatidiform mole: analysis of 113 cases. J Reprod Med. 2008;53(8):629-33.

11- Colgan TJ, Noor A, Nanji S, Chang MC, Kolomietz E. Molecular Diagnosis of Placental Hydatidiform Mole: Innovation and Outcomes. J Obstet Gynaecol Can. 2017;39(11):1049-52.

12- Tidy JA, Gillespie AM, Bright N, Radstone CR, Coleman RE, Hancock BW. Gestational trophoblastic disease: a study of the mode of evacuation and subsequent need for treatment with chemotherapy. Gynecol Oncol. 2000:30912.

13- Seckl MJ, Sebire NJ, Fisher RA, Golfier F, Massuger L, Sessa C, et al. Gestational trophoblastic disease: ESMO Clinical Practice Guidelines for diagnosis, treatment and follow-up. Ann Oncol. 2013;24(suppl_6):vi39-vi50.

14- Stevens FT, Katzorke N, Tempfer C, Kreimer U, Bizjak GI, Fleisch MC, et al. Gestational Trophoblastic Disorders: An Update in 2015. Geburtshilfe Franenheilked. 2015;75(10):1043-50.

15- FIGO Oncology Committee. FIGO staging for gestational trophoblastic neoplasia 2000: FIGO Oncology Committee. Int J Gynaecol Obstet. 2002;77(3):285-7.

16- Maestá I, Growdon WB, Goldstein DP, Bernstein MR, Horowitz NS, Rudge MVC, et al. Prognostic factors associated with time to hCG remission in patients with low-risk postmolar gestational trophoblastic neoplasia. Gynecol Oncol. 2013;130(2):312-6.

17- Mangili G, Lorusso D, Brown J, Pfisterer J, Massuger L, Vaughan M, et al. Trophoblastic disease review for di- agnosis and management: a joint report from the International Society for the Study of Trophoblastic Disease, European Organisation for the Treatment of Trophoblastic Disease, and the Gynecologic Cancer Inter Group. Int J Gynecol Cancer. 2014;24(9):S109-S16.

18- Ngan H, Kohorn EI, Cole LA, Kurman RJ, Kim SJ, Lurain JR, et al. Trophoblastic disease. Int J Gynaecol Obstet. 2012;119(S2).

19- Smith HO. Gestational trophoblastic disease epidemiology and trends. Clin Obstet Gynecol. 2003;46(3):541-56. 20- Fowler D, Lindsay I, Seckl M, Sebire N. Routine pre-evacuation ultrasound diagnosis of hydatidiform mole: experience of more than 1000 cases from a regional referral center. Ultrasound Obstet Gynecol. 2006;27(1):56-60. 21- Sebire NJ, Foskett M, Fisher RA, Rees H, Seckl M, Newlands E. Risk of partial and complete hydatidiform molar pregnancy in relation to maternal age. BJOG. 2002;109(1):99-102.

22- Altman AD, Bentley B, Murray S, Bentley JR. Maternal age-related rates of gestational trophoblastic disease. Obstet Gynecol. 2008;112(2 Pt 1):244-50.

23- Betrán AP, Ye J, Moller A-B, Zhang J, Gülmezoglu AM, Torloni MR. The Increasing Trend in Caesarean Section Rates: Global, Regional and National Estimates: 1990-2014. PLoS One. 2016;11(2):e0148343.

24- Bruce S, Sorosky J. Gestational Trophoblastic Disease [Updated 2017 Dec 4]. In: StatPearls [Internet]. Treasure Island (FL): StatPearls Publishing; 2018 Jan-. Available from: https://www.ncbi.nlm.nih.gov/books/ NBK470267/.

25- Rezk M, Marawan H, Dawood R, Masood A, Abo-Elnasr M. Prevalence and risk factors of iron-deficiency anaemia among pregnant women in rural districts of Menoufia governorate, Egypt. J Obstet Gynaecol. 2015;35(7):663-6.

26- Joneborg U, Marions L. Current clinical features of complete and partial hydatidiform mole in Sweden. J Reprod Med. 2014;59(1-2):51-5.

27- Sun SY, Melamed A, Goldstein DP, Bernstein MR, Horowitz NS, Moron AF, et al. Changing presentation of complete hydatidiform mole at the New England Trophoblastic Disease Center over the past three decades: does early diagnosis alter risk for gestational trophoblastic neoplasia? Gynecol Oncol. 2015;138(1):46-9.

28- Kirk E, Papageorghiou AT, Condous G, Bottomley $\mathrm{C}$, Bourne T. The accuracy of first trimester ultrasound in the diagnosis of hydatidiform mole. Ultrasound Obstet Gynecol. 2007;29(1):70-5. 
29- Delattre S, Han S, Moerman P, Billen J, Goffin F, Scharpe K, et al. Human Chorionic Gonadotropin Regression Curves after Partial or Complete Molar Pregnancy in Flanders: Are They Different from Regression Curves from the Eighties? Gynecol Obstet Invest. 2018;83(1):76-82. 30- Joneborg U, Folkvaljon Y. Temporal trends in incidence and outcome of hydatidiform mole: a retrospective cohort study. Acta Oncol. 2018:1-6.

31- Schmitt C, Doret M, Massardier J, Hajri T, Schott AM, Raudrant D, et al. Risk of gestational trophoblastic neoplasia after hCG normalisation according to hydatidiform mole type. Gynecol Oncol. 2013;130(1):86-9.

32- Eysbouts YK, Bulten J, Ottevanger PB, Thomas CM, Ten Kate-Booij MJ, van Herwaarden AE, et al. Trends in incidence for gestational trophoblastic disease over the last 20 years in a population-based study. Gynecol Oncol. 2016;140(1):70-5.

33- Atabaki pasdar F, Khooei A, Fazel A, Rastin M, Tabasi N, Peirouvi T, et al. DNA flow cytometric analysis in variable types of hydropic placentas. Iran J Reprod Med. 2015;13(5):269-74.

34- Xie Y, Pei X, Dong YU, Wu H, Wu J, Shi H, et al. Single nucleotide polymorphism-based microarray analysis for the diagnosis of hydatidiform moles. Mol Med Rep. 2016;14(1):137-44.

35- Fisher RA, Tommasi A, Short D, Kaur B, Seckl MJ, Sebire NJ. Clinical utility of selective molecular genotyping for diagnosis of partial hydatidiform mole; a retro- spective study from a regional trophoblastic disease unit. J Clin Pathol. 2014:jclinpath-2014-202517.

36- Vang R, Gupta M, Lee-Shu-Fune Wu AV, Yemelyanova RJK, Murphy KM, DeScipio C, et al. Diagnostic reproducibility of hydatidiform moles: ancillary techniques (p57 immunohistochemistry and molecular genotyping) improve morphologic diagnosis. Am J Surg Pathol. 2012;36(3):443.

37- Buza N, Hui P, editors. Immunohistochemistry and other ancillary techniques in the diagnosis of gestational trophoblastic diseases. Semin Diagn Pathol. 2014: Elsevier. 38- Sun SY, Melamed A, Joseph NT, Gockley AA, Goldstein DP, Bernstein MR, et al. Clinical Presentation of Complete Hydatidiform Mole and Partial Hydatidiform Mole at a Regional Trophoblastic Disease Center in the United States Over the Past 2 Decades. Int J Gynecol Cancer. 2016;26(2):367-70.

39-Sun SY, Goldstein DP, Bernstein MR, Horowitz NS, Mattar R, Maestá I, Braga A, Berkowitz RS. Maternal Near Miss According to World Health Organization Classification Among Women with a Hydatidiform Mole: Experience at the New England Trophoblastic Disease Center, 1994-2013. J Reprod Med. 2016 May-Jun;61(5-6):210-4.

40-Khachani I, Alami MH, and Bezad R. Implementation and Monitoring of a Gestational Trophoblastic Disease Management Program in a Tertiary Hospital in Morocco: Opportunities and Challenges. Obstet Gynecol Int. 2017; 2017: 5093472. 